\title{
Steponas Kolupaila's contribution to hydrological science development
}

\author{
Gintaras Valiuškevičius \\ Department of Hydrology and Climatology, Vilnius University, M. K. Čiurlionio 21, \\ 03101 Vilnius, Lithuania \\ Correspondence to: Gintaras Valiuškevičius (gintaras.valiuskevicius@gf.vu.lt)
}

Received: 10 March 2017 - Revised: 5 July 2017 - Accepted: 7 July 2017 - Published: 1 August 2017

\begin{abstract}
Steponas Kolupaila (1892-1964) was an important figure in 20th century hydrology and one of the pioneers of scientific water gauging in Europe. His research on the reliability of hydrological data and measurement methods was particularly important and contributed to the development of empirical hydrological calculation methods. Kolupaila was one of the first who standardised water-gauging methods internationally. He created several original hydrological and hydraulic calculation methods (his discharge assessment method for winter period was particularly significant). His innate abilities and frequent travel made Kolupaila a universal specialist in various fields and an active public figure. He revealed his multilayered scientific and cultural experiences in his most famous book, Bibliography of Hydrometry. This book introduced the unique European hydrologicalmeasurement and computation methods to the community of world hydrologists at that time and allowed the development and adaptation of these methods across the world.
\end{abstract}

\section{Introduction: important biographical background}

This year marks 125 years since the birth of the famous hydrologist Steponas Kolupaila (Fig. 1). His contribution to the development of hydrological-measurement methodology, hydraulic equations and eastern European river-regime analysis is well known to specialists worldwide. However, many people still fail to fully recognise his influence to the progress of hydrological research ideas in the 20th century.

Kolupaila (for a brief Curriculum Vitae, CV, and almost exhaustive list of publications see Gimbutas and Danys, 1974 or Kilkus, 2002) was born on 14 September 1892 in Tuminiškès near Aglona (at that time the village belonged to the Russian Empire, now it belongs to the Republic of Latvia). After graduating from the gymnasium in Mitau (now Jelgava) in 1911 he entered the Moscow Geodetic Institute (in Russian: Moskovskij Mezhevoj Institut). There Kolupaila attended the Engineering-reclamation Faculty and in 1915 he qualified as geodesy engineer. In the same year he began teaching hydrology and hydrometry at this institute and in 1919 he was elected professor.

The Russian Revolution was followed by political repression, and as a consequence Kolupaila moved to Lithua- nia in 1921. He taught disciplines related to geodesy, water management and hydraulics at Dotnuva Agricultural and Forestry School. Later he moved to Kaunas and began to work at Kaunas Technical College and at Kaunas University (from 1923 as an associate professor, from 1926 as an extraordinary professor, and from 1940 as an ordinary professor). In 1923 Kolupaila established the Lithuanian Hydrometric Service Office - the main organisation that operated hydrological research and supervised the network of stationary measurement stations in the country. In 1926 the first hydrometric instrument calibration laboratory (Fig. 1) in north-eastern Europe was established by his efforts in Kaunas; the laboratory has so far remained the only calibration institution in the Baltic countries (Ramešová and Mattas, 2010). In 1939-1940 Kolupaila published a two-volume textbook-monograph in Lithuanian, Hydrometry (Kolupaila, 1939, 1940a); it was the most significant publication in this field in Europe at that time (Pardé, 1965).

While he lived in Lithuania, Kolupaila was not only active in the field of hydrology. He was one of the founders of the Baltic States Geodesy Commission, which participated in the creation of a triangulation network around the Baltic Sea 


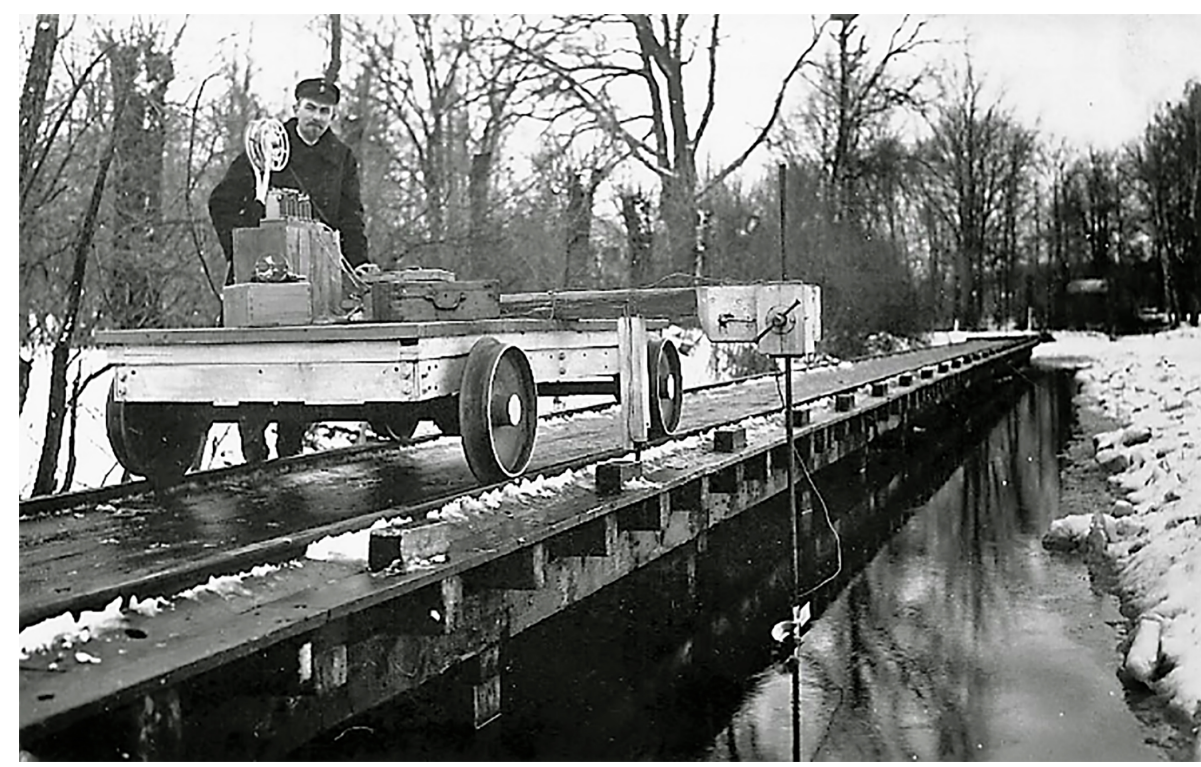

Figure 1. Steponas Kolupaila on Kaunas hydrometric instruments calibration field laboratory in 1926 (Keliauk.info, 2017).

(Wallén, 1929; Perrier, 1938). He regularly published results of geodetic and cartographic research in the scientific press (Kolupaila, 1925, 1926a, b, 1930d). Kolupaila was known as an active public figure in Lithuania: he was a member of geographers', scouts', photographers' and tourists' organisations, as well as a member and a leader of many bilateral cooperation societies (Gimbutas and Danys, 1974; Kilkus, 2002).

In 1940 sudden and ominous changes took place in Lithuania: in June 1940 country was occupied and annexed by the Soviet Union, and a year later, in June 1941, Lithuania was occupied by Germany. During the Second World War Kolupaila persistently continued his work: in 1940 he became a member of the Lithuanian Academy of Sciences and was elected head of the Department of Hydrology and Water Management at Kaunas Vytautas Magnus University. At the end of the war the majority of Lithuanian intellectuals were forced to flee from possible Soviet government repression. Kolupaila fled from Lithuania on 30 July 1944 (at the age of 52). He was a famous specialist and had extensive contacts in different countries, and this allowed him to establish himself abroad easily. He considered water-gauging research to be a priority in his activities. Therefore when in August 1944 L. A. Ott invited him to work as analyser in the hydrometric equipment factory "Ott" in Kempten (Bavaria, Germany; Hager, 2010), he accepted without hesitation. There Kolupaila continued his scientific work: he translated his $\mathrm{Hy}$ drometry into German and published next major work in Lithuanian - Hydraulics (Kolupaila, 1947a) - which he had prepared in Lithuania. The book was printed with help of the United Nations Relief and Rehabilitation Administration (UNRRA) the University and Hydraulic Institute of Munich
Technical University, at which he worked at that time (Joyce, 1949; Pardé, 1965).

In 1948 Kolupaila received an invitation to work in the Notre Dame University (Indiana, USA). On 5 January 1949 he arrived in the USA and started to work in the university as a professor in the Faculty of Civil Engineering (from 1955 he worked as a full professor, and from 1962 he became a professor emeritus; Davin, 1955). In the USA Kolupaila quickly joined in the scientific activities: he wrote articles and participated in the discussions on topical issues of hydraulics and gauging (Kolupaila, 1949, 1963; Kirpich et al., 1950; Kolupaila et al., 1953). While he was working in the Notre Dame University he devoted his greatest attention to the arrangement of his bibliographic archive.

At that time, discussions which were mainly attended by the American hydrology practitioners were fairly popular in the hydrological scientific journals. In these discussions Kolupaila noticed that American hydrologists often lack the theoretical and historical knowledge about hydrological measurements. He had a great archive of documents relative to these issues and decided to introduce hydrologicalmeasurement history to his colleagues. In 1960-1961 he published a detailed article about the early history of United States hydrometry (Kolupaila, 1960a, 1961a). In 1961 he published a book of 976 pages, Bibliography of Hydrometry (Kolupaila, 1961b), the most significant of Kolupaila's works and one which has been quoted in all classic hydrological and hydrometrical works so far. In the last year of his life Kolupaila collected a lot of additional bibliographical material, hoping to update this book, but he did not have time to publish this data. Kolupaila died on 9 April 1964. He is buried in Saint Casimir cemetery in Chicago. 


\section{Kolupaila - a theorist of hydrometry and hydraulics}

Kolupaila became interested in hydrometry when he was studying at the Moscow Geodetic Institute. The course of agricultural hydraulic engineering was taught by professor A. Shiryaev at that time (Moscow State University of Geodesy and Cartography, 2017). In 1915 he proposed that Kolupaila (who graduated from the institute that year) stay in Moscow and work as an assistant. Kolupaila had to specialise in hydrometry, and therefore in the same year he began attending lectures in hydrology at the Moscow Agricultural Academy. This course was taught by one of the pioneers of scientific hydrology in Russia, the founder and long-time leader of the Russian State Hydrological Institute, V. Glushkov (Lvovich, 1968; Spengler, 2009). Afterwards Kolupaila repeatedly mentioned that the innovative treatment of hydrology in this school had a significant influence on the formation of his scientific attitude (Kolupaila, 1924d, 1930c, 1932). From childhood onwards Kolupaila was extremely fascinated by engineers that he encountered at the time that his father was working as a medic in Russian Railways (later in his $\mathrm{CVs}$ he always characterised himself as an engineer first, and only after that did he list his other specialties and positions). Therefore, as his greatest scientific authorities he always considered the Russian hydrologist-engineers who have given him most of his professional knowledge in his youth: V. Glushkov, E. Opokov and A. Shiryaev (Kilkus, 2002). Subsequently, L. A. Ott and M. Pardé with whom he constantly collaborated, exchanged information and analysed topics of possible use of hydrometric equipment and eastern European river regimes have had a great influence on him (Pardé, 1965).

Hydrometry at that time was a science that had only just started developing at the time (Garbrecht, 1987; Dooge, 1999). Therefore the first of Kolupaila's works are related to the creation of the unified water measurement methodology. In 1918 (while he was still working in Moscow) he published the first Russian hydrometry textbook (Kollupailo, 1918). After returning to Lithuania Kolupaila worked in the Lithuanian Hydrometrical Office, whose main goal was to collect the data on the hydrological regime of country's rivers as soon as possible. They were mostly lacking the data on river discharges, and therefore questions about rivers hydraulics were especially important. The instruments of the time could not measure flow rate quickly, and therefore scientists attempted to estimate how many points are needed to perform the speed measurements in order to get accurate results. At the same time they were aiming to optimise the distribution of velocity measurement points in the channel and the form of water-current meter sensors. Kolupaila started to deal with these problems when he was studying and he showed interest in them until the end of his life.

In 1918 he published Hydrometry in Russian (Kollupailo, 1918), in which for the first time in the world the coefficients describing the distribution of the river water flow velocity by the depth were determined by hydraulic laws (Schaffernak, 1935; Zhelezniakov, 1968). The results of his work were subsequently used in Hulsing et al. (1966), which is reputed to be a classic work about river hydraulics. These authors did not have access to Kolupaila's works in Lithuanian, Russian and German (Kollupailo, 1925a, 1930f, 1940a, 1947a, b, 1957) and used his other publications which were published in English (Kolupaila, 1956, 1958, 1960b, 1961c). Links to his English articles also dominate in other works which refer to Kolupaila's contribution to research on the distribution of flow energy in open channels (Graf, 1966; Dickinson, 1967; Limerinos, 1970; Bjerketorp and Josefsson, 1985; Pelletier, 1988; Thibodeaux, 1994; Das, 2008; Morgenschweis, 2010; Engineering and Asset Management Unit Geo-Environmental Section, 2011). Kolupaila's discovered laws were also applied in other flow measurement methods (Cragwall, 1956; Dávid, 1973; Karasev, 1980; Engineering and Asset Management Unit Geo-Environmental Section, 2011).

Because only a small amount of data was available, the setting of daily discharges under the rating curve was a big problem (Kolupaila, 1924c). A reliable rating curve which allows discharge value to be estimated according to the water level can be formed only with the numerous measurement results (in identical conditions). In the first half of the 20th century the majority of Lithuanian rivers were frozen during cold periods of the year, and discharges were measured infrequently because of the often-observed ice phenomenon. While searching for opportunities to evaluate the discharges in winter periods, Kolupaila developed a method to calculate them with the summer discharge curve by applying special coefficients. A value of coefficient is computed for each discharge measurement as the ratio of measured discharge to the open-water discharge. Because the coefficient varies during the winter with time, as changes occur in the ice cover, its value for use on any given day is obtained by the interpolation method (Kolupaila, 1928a). It was a very important (and hardly studied) problem in countries where the rivers were frozen during the cold times of the year. After moving to Lithuania, Kolupaila was actively involved in activities of the international scientific community. Since the mid-1920s, he was in regular contact (by corresponding and meetings) with famous German, French, Russian, Polish, Latvian and Estonian hydrologists (V. Glushkov, D. Kocherin, L. A. Ott, M. Pardé, A. Rundo, P. Stakle, H. A. Velner). This allowed him to promote the discharge calculation method for winter (and other periods characterised by non-standard conditions) that he discovered and present it in the most important international conferences of that time. In 1928 he made a report about it in Tallinn (Kolupaila, 1928b) and later in Seville and Barcelona (Kolupaila, 1929), in Madrid (Kolupaila, 1930b), in Riga (Kolupaila, 1938b) and in Leningrad (Kollupailo, 1933; Kolupaila et al., 1934). The discharge ratio method (often called the "Lithuanian method") is still one of the most 
popular flow calculation methods at non-standard river conditions in the world (Rantz, 1982; Hyvärinen, 1985; Pelletier and Eng, 1988; Schmidt and Garcia, 2003; Klimenko and Garaishina, 2008; Morgenschweis, 2010; World Meteorological Organization, 2010).

Kolupaila is also considered to be a creator of the original equation for calculation of maximum discharges. In 1934 he reported for the first time about the opportunity to evaluate the maximum outflow in the absence of data (or with very small quantities of data) in accordance with the catchment hydrographical parameters (Kolupaila, 1934). Later the methodology was improved by applying the probability calculation (Kolupaila, 1936b, 1937b), and it is still popular in poorly researched regions (Karasev, 1980).

Kolupaila devoted a great deal of attention to the improvement of the water-current meter sensors. He was interested in this topic from the third decade of the 20th century, since the water-current meter calibration laboratory was installed in Kaunas (Kolupaila, 1933d). Most studies with generalisable results on this subject were published only after the Second World War (Kolupaila, 1947a, 1949, 1958; Kolupaila and Landauer, 1951; Colby and Kolupaila, 1964) when Kolupaila was able to verify his theoretical knowledge in the Ott company laboratory in Germany. His experience and knowledge were used there in practice to create new models of the water-current meter (Thibodeaux, 1994; Kilkus, 2002). His contribution was particularly important when the company constructed component rotor to the water-current meter "Ott Type V". For a few decades this model was the most commonly used instrument in Europe for measuring water flow velocity (Dickinson, 1967; Caesperlein, 1974; Frazier, 1974). The manufacturers of hydrometric equipment still remember Kolupaila's input to the creation of this new type of sensor (Ramešová and Mattas, 2010; VUVTGM, 2017).

Kolupaila sought to convey these innovations to his students (in Lithuania he was teaching at three different high schools) and summarised his research material in textbooks. Before the war he published Hydrometry (in Lithuanian; Kolupaila, 1939, 1940a). The use of the measurement methods and instrumentation in various countries were presented, with authentic examples, in this profusely illustrated work along with many specific indicators, methodologies and proposals of new theoretical and empirical equations (Pardé, 1965; Zhelezniakov, 1968; Karasev, 1980). In 1940 the hydrometric equipment company Ott offered to finance the release of this book in German. The war delayed the process (although in 1947 the work was translated) and the book publication failed (Kilkus, 2002). For the same reasons, the edition of Kolupaila's other book Hydraulics (1947a) was delayed. The publication was prepared in Kaunas (his students from his time here recall that in 1944 they already used a set of hydraulic formulas and tables multiplied by photocopiers; Macevičius, 1992) but the book was only published in Germany after the war.

\section{Eastern European hydrological studies}

Kolupaila greatly contributed to the research of rivers' hydrological regimes in Europe. His works introduced the specific (and unknown at that time) characteristics of eastern European waters to a world community of hydrologists (Fejér and Lászlóffy, 1986; Broc, 2010). He became interested in the hydrography and hydrology of large rivers in his youth, when in 1918-1921 he worked in the Main Administration of Russian Water Management Office. Letters, diaries and other details from the Kolupaila's personal archive show that at the time he participated in the development of largest hydraulic structure projects in Russia: the VolgaDon Canal, the Dnieper hydroelectric power plant (Dnieproges), the bridge over the Volga River near Saratov and others (Gimbutas and Danys, 1974). Many of these projects were finished after he had already left Russia. In the Main Administration of Russian Water Management Office he discovered a lot of the river water level and outflow measurement results which were never published before. They were subsequently used for the analysis of the eastern European river runoff. The majority of these research materials were published in French scientific journals, often conjointly with one of the most famous potamology specialist of that time, M. Pardé (Kolupaila and Pardé, 1933, 1934, 1936; Kolupaila, 1937a).

In 1921 Kolupaila brought back to Lithuania scores of data from hydrological studies that were carried out in this region. The continuous results of Nemunas River water level measurements near Smalininkai from the beginning of the 19 th century were among them. Kolupaila had an idea to restore the hydrological monitoring network in Lithuania. A month after his return from Russia he sailed the Lithuanian section of Nemunas River and took a look at the condition of all existing water measuring stations (Kolupaila, 1950). He was satisfied that Smalininkai water measurement station was still running and also began to tend to methodical maintenance and organisation of the operation in the hydrological stations. The material which he found in Moscow allowed him to restore the Smalininkai water station hydrological data series from 1811. The data were quickly checked, processed and published in local and international presses (Kolupaila, 1930e, 1933a, c; Kolupaila and Pardé, 1933). This data set was published in a special issue of Lithuanian hydrometric yearbook (Lietuvos hidrometrinis biuras, 1930), the importance of which was promptly noted by international journals (D. J. M., 1931). Currently Smalininkai water measuring station is one of the ten oldest continuously operating hydrological stations in the world (Macevičius, 1992; Jakimavičius, 2007; Jablonskis and Lasinskas, 2011). The Smalininkai station data are particularly important in analysing long-term trends in the temporal runoff distribution (Pekárová et al., 2003; Gosling and Arnell, 2011; Stonevičius et al., 2017).

Lithuania regained its independence only after the First World War: the country experienced a lack of engineering 
specialists, and also the majority of state institutions were not functioning or had just started working. Kolupaila arrived in the country at 29 years old without knowing Lithuanian, but he immediately started to participate in educational, scientific and engineering research programs. He quickly learned the language (his first publication in Lithuanian journal (Kolupaila, 1922) was published less than 1 year after arrival) and began to tend to the hydrological measurements. In 1923 the Lithuanian government commissioned him to establish the Lithuanian Hydrometric Office. From 1924 to 1931 80 new water-gauging stations were set up in the country's territory by this institution (which he was directing).

At that time in the Baltic states, hydrology was mostly considered as an ancillary branch of engineering, knowledge of which is essential in building, road constructions and reclamation. The main method of hydrological research was performing case-by-case expeditionary measurements. Scientists lacked for long-term data on the hydrological regime of the region's waters; in 1923 in all Baltic states there were only around 20 water measurement stations, which continuously operated for more than 30 years (Lasinskas, 1992). The governments of Lithuania, Latvia and Estonia were not keen to support applied research. Higher-education establishments in the Baltic states were still developing (Estonia's Tartu University was the only one from the old educational institutions which continued to operate), and in the beginning of the 1920s none of the hydrology-related subjects were taught there. Therefore, the most important task for Kolupaila was to collect as much basic information as possible, which would justify the necessity of hydrology as an independent science.

Information about the region's hydrography was necessary to develop the monitoring network. In 1920-1940 Kolupaila (using 1:84000 and 1:300 000 scale maps) estimated length and catchment areas of all Lithuanian rivers whose length exceeded $5 \mathrm{~km}$ and also evaluated the river bed slope and network density of major part of Nemunas River basin (Macevičius, 1992; Gailiušis et al., 2001). The hydrographical research results were regularly published in academic journals (over 20 articles on this topic were published within 10 years) and presented at international conferences (Kollupailo, 1925b, 1929; Kolupaila, 1927a, b, 1930a). Thanks to Kolupaila's efforts before Second World War, Lithuania became one of the most hydrologically explored regions in Europe. By 1936 one of the densest hydrological-station networks in Europe at the time was created in Lithuania: one station represented approximately $400 \mathrm{~km}^{2}$ of territory (Jakimavičius, 2007). Besides the water-level, temperature and ice-regime-change measurements, most of the stations were also recording water discharges. The collected data have been successfully used to optimise the country's hydrological station network: the majority of modern Lithuanian hydrological stations, which have been operating for more than 60 years, were established in places proposed by Kolupaila (Gailiušis et al., 2001; Jakimavičius, 2007). In the 1940s most hydrographic researches were summarised in the fundamental works (Kolupaila, 1933b, 1936a, 1940b), which became very popular and were updated and published repeatedly (Kolupaila, 1938a, 1950).

Thanks to Kolupaila's research, an active and thriving hydrology school was established in Lithuania. The most famous of Kolupaila's pupils (scientists as well as engineer practitioners) have had a great impact on the further development of Lithuanian hydrological science. Amongst his first pupils was L. Mižutavičius (after 1940 - L. Mingaudas) who was one of the Lithuanian hydroelectricity pioneers and helped Kolupaila publish hydrometric yearbooks and hydrographic maps. M. Lasinskas and J. Macevičius who worked with the first Lithuanian river cadastre (19591962) and contributed a lot to the improvement of geodetic research and hydrological calculation methods in Lithuania were also amongst those of Kolupaila's pupils who carried on his traditions. There were also pupils who developed his ideas abroad, e.g. L. Bajorūnas, who was the first in Lithuania to defend a dissertation on a hydrological subject for a doctoral degree of engineering in 1943, later worked for a long time in Detroit as director of the US Lake Survey Great Lakes Research Center. Even the most significant Lithuanian hydrologists, hydroelectricity specialists and water management engineers (J. Burneikis, A. Barisas, J. Jablonskis, B. Gailiušis, P. Punys, K. Kilkus) state that their scientific ideas are based on basic knowledge which was formulated thanks to Kolupaila's hydrology school (Macevičius, 1992; Gailiušis et al., 2001; Kilkus, 2002; Kilkus and Valiuškevičius, 2006).

\section{Bibliography of Hydrometry}

Kolupaila had an idiosyncratic personality, which was a result of his miscellaneous life experiences: life in various countries (Latvia, Russia, Lithuania, Germany, USA), knowledge of many languages (his native language in his parents' home was Polish, in school he studied in Russian, and subsequently he spoke fluently in Lithuanian, German, French and English; he wrote scientific articles in 8 different languages) and expertise in different engineering areas (geodesy, hydrology, hydraulics). His thoroughness and extensive opportunities to explore the world enabled him to study in depth the professional literature which was published in different countries and languages.

Kolupaila began collecting and systematising material about hydrometric research in his youth (when he started to teach this discipline). He used some of the data from his card file collection in his first textbook (Kollupailo, 1918). During the post-revolution chaos in Russia, Kolupaila managed to preserve and expand his archives considerably (he collected the old documents from organisations destroyed by the Bolshevik government). He was not able to bring along most of the data when he was leaving the country, and there- 
fore he tried to print as much as possible of the material in the books. At that time Kolupaila did not have the opportunity to print a new large-scale textbook of high quality, and therefore he decided to update his Hydrometry (1918) and publish its revised and updated edition. This was the main reason for printing the two-volume publication Hydrometry lecture material (in Russian) (Kollupailo, 1921a, b). The second volume, Manual of Literature by Hydrometry (Kollupailo, 1921b), was notably important. In this 300-page book, Kolupaila summarised his material about hydrological measurements for the first time. The book describes in detail 592 of the most important literature sources in this field. Most of the data in this book were collected from Russian, German and Austro-Hungarian publications, and therefore it mostly represents the hydrometric research traditions of the central and eastern European regions (Kresser, 1964). It was the first large-scale literature review about water measurements with precise bibliographic data and a detailed description of the publications in the world. Later (already living in the United States) Kolupaila described the publishing of this book (Kolupaila, 1959a, p. 11):

"I had collected the card file of hydrometric literature. When I was repatriating to Lithuania, I would have to leave it there. Friends asked me to publish at least their summary. My wife wrote the text using a typewriter in various fonts, I had concealed a stockpile of paper, whereas the lithographic printing house printed the booklet in 3 nights (...) for a bottle of spirits (...)"

Despite the difficult conditions, Kolupaila succeeded in bringing a part of the archive to Lithuania. There he continued the material systematisation and collected new data. During this period he discovered the majority of the information in Königsberg and Berlin archives. In the 1930s he often visited there in search of hydrological-measurement data of established German water-measuring stations (which belonged to the territory of Lithuania after the First World War; Macevičius, 1992). In order to fill the gaps in data sequences, Kolupaila often needed to find additional information about the measurement methods and equipment used. The bibliographic material file grew steadily: in 1921 there were about 600, in 1948 there were about 8000 and in 1965 there were about 25000 cards describing the works concerning hydraulics and gauging (Masiokas, 1969).

Kolupaila was especially interested in the construction and use of water-current meters, hence approximately half of his card file consisting of the data about publications concerning measurements of the water-flow velocity in the rivers. Kolupaila collected the majority of this material during his visits to libraries in various European cities (Berlin, Budapest, Königsberg, Moscow, Paris, Madrid, St Petersburg - then Leningrad - and Vienna). His students and family members say that each time the professor attended a conference abroad, he visited at least one of the nearest scientific libraries and searched for new articles regarding hydrological gauging (Kilkus, 2002). At that time Kolupaila had already noticed clear differences between hydrologicalmeasurement traditions in Europe and in the USA (Kolupaila, 1938c). In 1944 when he fled from Lithuania, he managed to bring along a few thousand classified cards containing descriptions of publications. Kolupaila continued his bibliographical research even while he was living in a refugee camp in Kempten. The authors who analysed his biography (Gimbutas and Danys, 1974; Macevičius, 1992) reported that, in 1948 in Kempten, Kolupaila published a small booklet in German titled Literatur über Hydrometrie but none of its copies survived to the present day.

New possibilities to further analyse the collected bibliographical information emerged when Kolupaila started working at Notre Dame University. His initial publications, in which the majority of the card file material was used, were dedicated to a historical overview of the hydrological-measurement development (Kolupaila, 1959b, 1960a, 1961a). These articles attracted great interest from American hydrologists, especially the article that appeared in 1960, which caused a very lively discussion in the Journal of the Hydraulics Division. Kolupaila was invited to edit important hydraulics textbooks (Chow, 1959), and his works were noticed by science history researchers (Sivin et al., 1960; Woolf and Cattell, 1963). At the same time, Kolupaila published a comprehensive study about the historical development of water measurement in hydraulic structures and power plants (Kolupaila, 1960b). His enthusiasm did not go unnoticed: in 1960 (through the direction of the Notre Dame University), he received a 25000 USD grant from the National Science Foundation to write a book about the hydrometric literature (Gimbutas and Danys, 1974; Kilkus, 2002).

Bibliography of Hydrometry was published at the beginning of 1961. This publication contained 7370 references on books and articles in the hydraulic measurement field in 36 different languages. It referred to 4500 researchers from all over the world. All references were picked out from Kolupaila's personal card files which at that time amounted to 22000 records. The book consists of 26 chapters. The fact that in most cases Kolupaila announced publications by directly referring to them is particularly important (it helped to avoid distortion of facts, which is often inherent in bibliographical books). Most of the material in the book was focused on describing the hydrological gauging achievements made during the last 50 years in Europe and North America; but there were also some articles which reviewed ancient methods used in countries as far afield as Egypt, Central Asia and China. In his book Kolupaila described the littleknown instrumental measurement methods from 17th and 18th centuries and he was one of the first in the world to do so (Lászlôffy, 1965; Quintela, 1991; Zhang et al., 2015). The book was notably important in the context of hydrological knowledge at the time as it allowed hydrologists who were applying empirical research methods to better understand the obtained results and compare their achievements with the global practice (Sperling, 1964; Pardé, 1965; Syden- 
ham, 1978; Dooge, 1974, 1999, 2004; Hager, 2009). The authors of classic hydrometry textbooks (Boiten, 2007; Morgenschweis, 2010) have used this book as a base up to the present day. Kolupaila's ability to read and write in different languages has enabled English-speaking scientists to get to know the achievements of small countries in the field of water measurements. The publication was announced and discussed in important hydrological journals (Lászlôffy, 1961). The "Report of Committee on Hydrometry" of the International Association of Hydrological Sciences (Langbein et al., 1964, p. 832) wrote the following:

"This publication was well accepted by the hydrologists and bibliographers in many countries all around the world. To bring this publication up to date, supplementary issues should be published at regular intervals." Bibliography of $\mathrm{Hy}$ drometry is a book that has affected the hydrological knowledge paradigm. To many researchers it revealed the diversity of early hydrological investigations which were previously unfamiliar and demonstrated that hydrology is a science with a difficult and extremely long development evolution. After publication of this book Kolupaila quickly gained international recognition. He was quoted in textbooks in many countries and was invited to lectures at major scientific events. The Hungarian society of hydrologists even elected him its honorary member (Magyar Hydrológiai Társaság, 2017).

Kolupaila continued his work and hoped to get financing for the additional volume publication. Although he collected a lot of additional data after 1961, unfortunately he did not have time to print it (in 1964 the scientist died after a short and dangerous illness).

\section{Concluding remarks}

In this paper we treated only Kolupaila's most important achievements in hydrology, hydraulics and water measurement. The paper length limits the possibilities to give an overview of many of his other works. Kolupaila was not only an active scientist who analysed very different topics (hydrology, hydraulics, dams, measurements, geodesy, land reclamation and meteorology). During his lifetime, he published more than 500 articles (Kilkus, 2002). Experience gained in multilingual and tumultuous eastern Europe in his youth allowed him later to express himself actively in science as well as in society, politics and the arts. While living in Lithuania and in the USA he was a member of a few dozen scientific, social, tourism and sports associations. The subjects of his articles in Lithuanian press (which were printed almost every week) were extremely varied: travel descriptions, energy problems, obituaries for famous personalities, education problems, art performances reviews and so on (Gimbutas and Danys, 1974).

Kolupaila was also known as an activist for the scout movement; he was one of the pioneers of this movement in Lithuania. He organised many trips and kayak tours for young people. Kolupaila not only described the visited objects in his publications but also actively photographed them. His archive of photographs (most of which cover the period from 1921 to 1944) is currently considered as one of the greatest and one of the most important authentic image collections of that time Lithuania. Kolupaila is also regarded as the pioneer of colour photography in Lithuania (Lietuvos fotografija, 2017).

There is no doubt that on a global scale Kolupaila's biggest contribution is the analysis of the water-measurement problem and its history. The late publication of his articles in English determined that his impact to hydrology scientific development in the 20th century has not yet been adequately assessed. Although his works are mentioned among the most important hydrometry research works of all time, only a small portion of the information they contain is often used. We hope that this article will encourage interest in Kolupaila's other works which to this day are important to the development of hydrology as well as many other geosciences.

Data availability. No data sets were used in this article.

Competing interests. The author declares that he has no conflict of interest.

Acknowledgements. Thanks are due to the Editor, Maurits Ersten, and to two anonymous referees for their helpful comments.

Edited by: Maurits Ertsen

Reviewed by: two anonymous referees

\section{References}

Bjerketorp, A. and Josefsson, L.: Vatienföring genom cirkulära brotrummor. Beräkningssätt under olika hydrauliska betingelser [Water flow in circular weir. The calculation methods under different hydraulic conditions], Uppsala, Institutionen för markvetenskap Avdelningen för lantbrukets hydroteknik, 22 pp., 1985 (in Swedish).

Boiten, W.: Hydrometry, Taylor \& Francis, New York, 248 pp., 2007.

Broc, N.: Une histoire de la géographie physique en France (XIXeXXe siècles) - Les hommes-Les æuvres-Les idées, Presses Universitaires de Perpignan, Perpignan, 716 pp., 2010.

Caesperlein, A.: Historical development of hydrometry, Three centuries of scientific hydrology, Key papers submitted on the occasion of the celebration of the Tercentenary of Scientific Hydrology, Paris, 9-12 September 1974, 54-63, 1974.

Chow, V. T.: Open-Channel Hydraulics, McGraw-Hill Book Company, New York, 680 pp., 1959.

Colby, B. R. and Kolupaila, S.: Comments on "Accuracy of Current Meter Measurements,” by R. W. Carter and I. E. Johnson, J. Hydr. Eng. Div., 90, 349-355, 1964. 
Cragwall, J. S.: Indirect methods of river discharge measurement, Proceedings of the Sixth Hydraulics Conference arranged by the Iowa Institute of Hydraulic Research, 13-15 June 1955, 35-59, Iowa City, 1956.

Das, M. M.: Open Channel Flow, PHI Learning Pvt. Ltd., New Delhi, 360 pp., 2008.

Dávid, L. J.: The air-bubble method of flow measurement and its application, Hydrometry: Proceedings of the Koblenz Symposium, 1, 362-373, UNESCO - WMO - IAHS, 1973.

Davin, D.: Student Engineers Learn Techniques of Building Dams, A Magazine of the University of Notre Dame, 8, 16-17, 1955.

Quintela, A. C.: Estevâo Cabral's pioneering contribution to open channel hydrometry, Hydrological Sciences, 36, 241-246, 1991.

Dickinson, W. T.: Accuracy of discharge determinations, Hydrology papers of Colorado state university, Fort Colins, 62 pp., 1967.

D. J. M.: Review: II Jahrbuch Des Hydrometrischen Büros Litauens by Steponas Kolupaila, Geogr. J., 78, 306-307, 1931.

Dooge, J. C. I.: The development of hydrological concepts in Britain and Ireland between 1674 and 1874, Hydrological Sciences Bulletin, 19, 279-302, 1974.

Dooge, J. C. I.: The Emergence of Scientific Hydrology in the Twentieth Century, Advances in water science, 10, 202-214, 1999.

Dooge, J. C. I.: Background to modern hydrology, The Basis of Civilization - Water Science?, Proceedings of the UNESCO/lAHS/IWHA symposium held in Rome, December 2003, 3-12, 2004.

Engineering and Asset Management Unit Geo-Environmental Section: Hydraulics manual, Oregon Department of Transportation Highway Division, 2011.

Fejér, L. and Lászlóffy, W.: Á Hidrometria Magyarországi Fejlődése (1700-1945) [Development of hydrometry in Hungary, Budapest], 194 pp., 1986 (in Hungarian with English and German summary).

Frazier, A. H.: Water current meters in the Smithsonian collections of the National museum of history and technology, Washington, Smithsonian Institution Press, 108 pp., 1974.

Gailiušis, B., Jablonskis, J., and Kovalenkovienè, M.: Lietuvos upès. Hidrografija ir nuotekis [The Lithuanian Rivers. Hydrography and runoff], Kaunas, LEI, 796 pp., 2001 (in Lithuanian with English summary).

Garbrecht, G.: Hydraulics and Hydraulic Research. A Historical Review, Rotterdam and Boston, Balkema, 362 pp., 1987.

Gimbutas, J. and Danys, J. V.: Steponas Kolupaila, Chicago, 464 pp., 1974 (in Lithuanian with English summary).

Gosling, S. N. and Arnell, N. W.: Simulating current global river runoff with a global hydrological model: model revisions, validation, and sensitivity analysis, Hydrol. Process., 25, 1129-1145, 2011.

Graf, W. H.: On the Determination of the Roughness Coefficient in Natural and Artificial Waterways, International Association of Scientific Hydrology, Bulletin, 11, 59-68, 1966.

Hager, W. H.: Hydraulicians in Europe 1800-2000, Volume 2: A bibliographical dictionary of leaders in hydraulic engineering and fluid mechanics, Taylor \& Francis, Zurich, 950 pp., 2009.

Hager, W. H.: Kolupaila, in: Water Engineering and Management through Time - Learning from History, edited by: Cabrera, E. and Arregui, F., New York, USA, CRC Press, 152 pp., 2010.
Hulsing, H., Smith, W., and Cobb, E. D.: Velocity-Head Coefficients in Open Channels. Geological Survey Water-Supply Paper 1869-C, United States Government Printing Office, Washington, 56 pp., 1966.

Hyvärinen, V.: River discharge in Finland, Publications of the Water Research Institute, National Board of Waters, Finland, 59, 23 pp., 1985.

Jablonskis, J. and Lasinskas, M.: Nemuno stacionariems hidrometriniams tyrimams 200 metu [The 200th anniversary of stationary hydrometric investigations of the river Nemunas], Energetika, 57, 34-43, 2011 (in Lithuanian with English summary).

Jakimavičius, D.: Stacionarieji hidrologiniai matavimai Lietuvos upèse 1810-2005 metais [Stationary hydrological measurements in Lithuania during 1810-2005], Annales Geographicae, 40, 6171, 2007 (in Lithuanian with English summary).

Joyce, E.: Escape From Cold War - Lithuanian Professor Finds Haven at ND, The Notre Dame Scholastic, 90, 14, 1949.

Karasev, I. F.: River hydrometry and water resources accounting, Leningrad, Gidrometeoizdat, 310 pp., 1980 (in Russian).

Keliauk.info: Hydrometric laboratory, available at: http://www. keliauk.info/hidro_lab.html, last access: 7 March 2017.

Kilkus, K.: Profesorius Steponas Kolupaila: gyvenimas skirtas Nemunui [Professor Steponas Kolupaila: Life intended to Nemunas River], Vilnius, Valgra, 116 pp., 2002 (in Lithuanian).

Kilkus, K. and Valiuškevičius, G.: Antano Bariso hidrologija [Hydrology according to Dr. Antanas Barisas], Vilnius, Vilnius University Press, 168 pp., 2006 (in Lithuanian with English summary).

Kirpich, P., Hodges, P., Davison, A., Kolupaila, S., Mitchell, W., Escoffier, F., and Vonseggern, M.: Integrating the Equation of Nonuniform Flow - discussion, T. Am. Soc. Civ. Eng., 115, 89$106,1950$.

Klimenko, D. E. and Garaishina, M. E.: Calculation of water flow in the period of ice on the rivers in the absence of observational data, Geograficheskij Vestnik, 1, 155-170, 2008 (in Russian).

Kollupailo, S. I.: Hydrometry: short theoretical and practical guidance, Moscow, Moscow Geodetic Institute, 268 pp., 1918 (in Russian).

Kollupailo, S. I.: Hydrometry lecture material, 1. Why do we need Hydrometry, Moscow, Institute of Measurement, 306 pp., 1921a (in Russian).

Kollupailo, S. I.: Hydrometry lecture material, 2. Manual of Literature by Hydrometry, Moscow, Institute of Measurement, 306 pp., 1921b (in Russian).

Kollupailo, S. I.: Typical coefficients of current meters, in: First Russian hydrologists Congress works, edited by: Bogdanov, N. F., Leningrad, 322-326, 1925a.

Kollupailo, S. I.: Work of Lithuanian Hydrometry Office, in: First Russian hydrologists Congress works, edited by: Bogdanov, N. F., Leningrad, 95-96, 1925b (in Russian).

Kollupailo, S. I.: Achievements of Lithuanian Hydrometry Office Research, in: 2nd Russian hydrologists Congress works, edited by: Bogdanov, N. F., Leningrad, 133-135, 1929 (in Russian).

Kollupailo, S. I.: The drafting and the use of rating curve in abnormal conditions, in: Notes of Russian State Hydrological Institute, edited by: Glushkov, V. G., 10, 191-215, 1933 (in Russian with German summary). 
Kolupaila, S., Collins, A., Olson, R., Robertson, J., and Ross, D.: Effect Of Entrance Conditions On Diffuser Flow-Discussion, T. Am. Soc. Civ. Eng., 118, 1092-1097, 1953.

Kolupaila, S. and Landauer, A.: Modellversuche und Flügelmessungen in schrägen Strömungen, Die Wasserwirtschaft, 41, 147151,1951

Kolupaila, S., Leppik, E., and Rundo, A.: The unification of hydrometric techniques work, IV Hydrological Conference of the Baltic countries Proceedings, Leningrad, 21-29, 1934.

Kolupaila, S. and Pardé, M.: Le régime des cours d'eau de l'Europe orientale, Revue de géographie alpine, 21, 651-748, 1933.

Kolupaila, S. and Pardé, M.: La Volga: étude hydrologique, Annales de Géographie, 43, 32-48, 1934.

Kolupaila, S. and Pardé, M.: Documents nouveaux sur la Volga, Annales de Géographie, 253, 90-95, 1936.

Kolupaila, S.: Medžiaga Lietuvos klimatologijai [Lithuania climate data], Kosmos, 3-4, 40-46, 1922 (in Lithuanian).

Kolupaila, S.: Dèl “debito kreivujụ” [About "Rating curves”], Technika, 1, 125-133, 1924c (in Lithuanian).

Kolupaila, S.: Hidrologo E. Oppokovo jubiliejus [Hydrologists E. Oppokov anniversary], Kosmos, 5, 182-183, 1924d (in Lithuanian).

Kolupaila, S.: Kauno niveliacijụ reperiai [Leveling benchmarks in Kaunas], Technika, 2, 128-156, 1925 (in Lithuanian).

Kolupaila, S.: Lietuvos niveliacijos, Levelings in Lithuania, Matininkas, 1, 2-7, 1926a (in Lithuanian).

Kolupaila, S.: Pabaltijo geodezinè komisija [Baltic States Geodesy Commission], Matininkas, 1, 7-11, 1926b (in Lithuanian).

Kolupaila, S.: Die hydrometrischen Arbeiten in Litauen, Kaunas, Wasserstrassenverwaltung des Verkehrsministeriums Litauens, Hydrometrisches Büro, 32 pp., 1927a.

Kolupaila, S.: Eine Übersicht der Tätigkeit des Hidrometrischen Büros Litauens, in: Die erste Hydrologische und Hydrometrische Konferenz der Baltischen Staaten in Riga. Protokolle und Referate, edited by: Stakle, P., 30-45 pp., 1927b.

Kolupaila, S.: Žiemos debito skaičiavimas [Winter discharge calculation], Technika, 4, 120-153, 1928a (in Lithuanian with French summary).

Kolupaila, S.: Die Berechnung der Winterabflussmengen, II Baltische Hydrologische und Hydrometrische Konferenz, 1722 June 1928, Tallin, Verkehrsministerium Estlands, 19 pp., $1928 b$.

Kolupaila, S.: Methoden der Bestimmung der Winterabflussmengen, Actas Memorias de la Conferencia Mundial de la Energia, Sesion Especial de Barcelona, 2, 653-676, 1929.

Kolupaila, S.: Sur l'activité du bureau hydrométrique de la Lithuanie, III-me Conférence Hydrologique des États Baltiques, 7-11 May 1930, Warszawa, 8 pp., 1930a.

Kolupaila, S.: Ecoulement de cours d'eau pendant la periode de congelation, Congreso Internacional de Oceanografia, Hidrografia Marina e Hidrologia Continental, Madrid, 30 pp., 1930 b.

Kolupaila, S.: Dviem Rusijos hidrologam paminèti: Nikolaj Maksimovič ir Dimitrij Kočerin [In memoriam two Russian hydrologists: Nikolaj Maksimovich and Dimitrij Kocherin], Kosmos, 11, 30, 1930c (in Lithuanian).

Kolupaila, S.: Mūsụ geodezijos vadovèliai [Our Geodesy Textbooks], Žemètvarka ir melioracija, 4, 64-66, 1930d (in Lithuanian).
Kolupaila, S.: Nemuno užšalimai per 120 m, (1811-1930) [Nemunas freezing within 120 years (1811-1930)], Kosmos, 11, 299_ 305, 1930e (in Lithuanian).

Kolupaila, S.: Über die Verteilung der Geschwindigkeiten auf der Lotrechten des Stromes, III Hydrologische Konferenz der Baltischen Staaten, Warschau, 28 pp., 1930f.

Kolupaila, S.: Neriai tirti ekspedicija prieš 75 metus [Research expedition in Neris River 75 years ago], Naujoji Romuva, 42, 900 902, 1932 (in Lithuanian).

Kolupaila, S.: Die Bestimmung des Abflusses des Memelstromes (Nemunas) 1812-1932, IV Hydrologische Konferenz der Baltischen Staaten, Leningrad, 14 pp., 1933a.

Kolupaila, S.: Mūsụ vandens keliai [Our waterways], Kaunas, 95 pp., 1933b (in Lithuanian).

Kolupaila, S.: Ökar Memel verkligen? [Increases the Nemunas River really?], Terra, Geografiska Sallskapets i Finland Tidskrift, 45, 121-124, 1933c (in Swedish with German summary).

Kolupaila, S.: Vergleichstarierungen der hydrometrischen Flügel, Leningrad, 37 pp., $1933 d$.

Kolupaila, S.: Naujos formulès Lietuvos upiụ maksimaliam debitui skaičiuoti [New formulas to calculate maximum outflow of Lithuanian rivers], Žemètvarka ir melioracija, 25, 3-27, 1934 (in Lithuanian).

Kolupaila, S.: Nevėžis [Nevėžis River], Kaunas, 125 pp., 1936a (in Lithuanian).

Kolupaila, S.: Sur le débit maximal des fleuves de la Lithuanie, in V Conférence hydrologique des États Baltiques, Finlande, Juin 1936, Rapport IB, Helsinki, 11 pp., 1936 b.

Kolupaila, S.: Le Niemen, etude hydrologique, Revue de Geograpie Alpine, 25, 381-409, 1937a.

Kolupaila, S.: Maksimalinio debito tikimybė [The maximum discharge probability], Žemètvarka ir melioracija, 11, 14-20, 1937b (in Lithuanian).

Kolupaila, S.: Mūsụ vandens keliai (2-asis leidimas), Our waterways, 2nd edition, Kaunas, 208 pp., 1938a (in Lithuanian).

Kolupaila, S.: The river flow beneath the ice, Riga, 12 pp., 1938 b.

Kolupaila, S.: Hidrometriniai darbai Jungtinese Amerikos Valstybėse, Hydrometric works USA, Žemėtvarka ir melioracija, 12, 177-187, 1938c (in Lithuanian).

Kolupaila, S.: Hidrometrija I [Hydrometry I], Kaunas, 396 pp., 1939 (in Lithuanian).

Kolupaila, S.: Hidrometrija II [Hydrometry II], Kaunas, 475 pp., 1940a (in Lithuanian).

Kolupaila, S.: Nemunas [Nemunas River], Kaunas, 220 pp., 1940b (in Lithuanian).

Kolupaila, S.: Hidraulika [Hydraulics], Kempten, 288 pp., 1947a (in Lithuanian).

Kolupaila, S.: Zur Frage der Konstantenbestimmung des hydrometrischen Flügels, A. Ott, Kempten, 17 pp., $1947 \mathrm{~b}$.

Kolupaila, S.: Recent Developments in Current-Meter Design, Transactions, American Geophysical Union, 30, 916-918, 1949.

Kolupaila, S.: Nemunas (2-asis leidimas) [Nemunas River, 2nd edition], Chicago, 237 pp., 1950.

Kolupaila, S.: Methods of determination of the kinetic energy factor, The Port Engineer, 5, 12-18, 1956.

Kolupaila, S.: Zur Frage der Vertikalgeschwindigskeits-kurve in natürlichen Strömen, Österreichische Wasserwirtschaft, 9, 1314, 1957. 
Kolupaila, S.: Use of current meters in turbulent and divergent channels, Association Internationale d'Hydrologie Scientifique, Assemble generale de Toronto, Comptes rendus ey reports, 1, 437444, 1958.

Kolupaila, S.: Hidrometrijos bibliografija [About bibliography of hydrometry], Technikos žodis, 5, 11, 1959a (in Lithuanian).

Kolupaila, S.: The study of hydrology in Eastern Europe, International Geology Review, 1, 94-98, 1959b.

Kolupaila, S.: Early History of Hydrometry in the United States, J. Hydr. Eng. Div., 86, 1-51, 1960a.

Kolupaila, S.: Water measurement in hydraulic structures and power plants (Historical sketch), La Houille Blanche, 15, 344-363, 1960b.

Kolupaila, S.: Early History of Hydrometry in the United States (closer), J. Hydr. Eng. Div., 87, 175-181, 1961a.

Kolupaila, S.: Bibliography of Hydrometry, Notre Dame, Indiana, 976 pp., $1961 b$.

Kolupaila, S.: Water surface profiles in irregular natural streams, American Society of Civil Engineers Proceedings, 87, 271-272, 1961c.

Kolupaila, S.: Discussion of Extention of rating curves by field surveys by Sittner, J. Hydr. Eng. Div., 89, 205-207, 1963.

Langbein, W. B., Szesztay, K., and Volk, J.: Report of Committee on Hydrometry, IAHS Publication, 65, 381-383, 1964.

Kresser, W.: Kolupaila S., Österreichische Wasserwirtschaft, 16, 236, 1964.

Lasinskas, M.: Hidrometriniai darbai Lietuvoje iki 1923 m, [Hydrometric research in Lithuania before 1923, before foundation of Hydrometric Bureau], Hidrometeorologijos straipsniai, 15, 5057, 1992 (in Lithuanian with English summary).

Lászlôffy, W.: Kolupaila, Steponas, Dr. Eng.: Bibliography of Hydrometry, International Association of Scientific Hydrology, Bulletin, 6, 83-85, 1961.

Lászlóffy, W.: Terrains et bassins représentatifs et expérimentaux de Hongrie, International Association of Scientific Hydrology, Bulletin, 10, 76-80, 1965.

Lietuvos fotografija: Stepono Kolupailos (1892-1964) kūrybinis palikimas, available at: http://www.photography.lt/lt.php/ NAUJIENOS?id=504\&type=1, last access: 14 February 2017.

Lietuvos hidrometrinis biuras: Hidrometrinis metraštis. 2. Nemuno matavimai Smalininkuose 1811-1930 m [Hydrometric Yearbook. 2. Nemunas measurements in Smalininkai 1811-1930], Kaunas, 376 pp., 1930 (in Lithuanian with German summary).

Limerinos, J. T.: Determination of the Manning Coefficient From Measured Bed Roughness in Natural Channels, Studies of Flow in Alluvial Channels, Geological survey water-supply paper, 1898 B, United States Government Printing Office, Washington, 53 pp., 1970.

Lvovich, M. I.: Viktor Grigorjevich Glushkov (1883-1939), Leningrad, Hidrometeoizdat, 119 pp., 1968 (in Russian).

Macevičius, J.: Steponas Kolupaila (1892-1964), Hidrometeorologijos straipsniai, 15, 177-198, 1992 (in Lithuanian with English summary).

Magyar Hydrológiai Társaság: Kitüntetettjei. Tiszteleti tagok névsora [Awards. Honorary members list], available at: www.hidrologia.hu/mht/letoltes/_kituntetettek.doc, last access: 10 March 2017 (in Hungarian).
Masiokas, B.: Kai kurios publikacijos apie prof. Steponą Kolupailą [Some publications about prof. Steponas Kolupaila], Darbininkas, 25, 1969 (in Lithuanian).

Morgenschweis, G.: Hydrometrie. Theorie und Praxis der Durchflussmessung in offenen Gerinnen, Springer-Verlag, Berlin, 581 pp., 2010.

Moscow State University of Geodesy and Cartography: History of University, available at: http://www.miigaik.ru/about/history, last access: 5 February 2017 (in Russian).

Pardé, M.: Sur un très grand hydrologue récemment disparu: le Professeur Steponas Kolupaila, Annales de Géographie, 74, 318321, 1965.

Pekárová, P., Miklánek, P., and Pekár, J.: Spatial and temporal runoff oscillation analysis of the main rivers of the world during the 19th-20th centuries, J. Hydrol., 274, 62-79, 2003.

Pelletier, P. M. and Eng, M.: Techniques used by water survey of Canada for measurement and computation of streamflow under ice condition, Canada Inland Waters Directorate, Montreal, 28 pp., 1988.

Pelletier, P. M.: Uncertainties in the single determination of river discharge: a literature review, Can. J. Civil Eng., 15, 834-850, 1988.

Perrier, G.: Organisations internationales. Trois assemblées scientifiques internationales en 1938, B. Geod., 59, 265-324, 1938.

Ramešová, L. and Mattas, D.: Česká kalibrační stanice vodoměrných vrtulí. Nežádoucí jevy v procesu kalibrace a jejich eliminace [Czech current meters calibration station. The adverse events in process of the calibration and their elimination], Praha, Vydal Výzkumný ústav vodohospodářský T. G. Masaryka, 80 pp., 2010 (in Czech).

Rantz, S. E.: Measurement and Computation of Streamflow: Volume 2. Computation of Discharge, Geological Survey WaterSupply Paper, 2175, 285-389, 1982.

Schaffernak, F.: Hydrographie, Wien, Verlag von Julius Springer, 439 pp., 1935.

Schmidt, A. R. and Garcia, M. H.: Theoretical examination of historical shifts and adjustments to stage-discharge rating curves, World Water and Environmental Resources Congress 2003, 23 26 June 2003, Philadelphia, PA, 1089-1098, 2003.

Sivin, N., Woolf, H., and Bosson, P. B.: Eighty-Fifth Critical Bibliography of the History of Science and Its Cultural Influences (To 1 January 1960), Isis, 51, 371-484, 1960.

Spengler, O.: About Hydrological Institute, Lema, Sankt Peterburg, 135 pp., 2009 (in Russian).

Sperling, W.: Kolupaila S., International Association of Scientific Hydrology, Bulletin, 9, 127-129, 1964.

Stonevičius, E., Rimkus, E., Štaras, A., Kažys, J., and Valiuškevičius, G.: Climate change impact on the Nemunas River basin hydrology in the 21st century, Boreal Environ. Res., 22, 49-65, 2017.

Sydenham, P. H.: Source guide to history of measurement technology material. Part 2: Source material in the printed medium, Meas. Control., 11, 103-116, 1978.

Thibodeaux, K. G.: Review of Literature on the Testing of PointVelocity Current Meters, U.S. Geological Survey Open-File Report 94-123, 48 pp., 1994.

VUVTGM (Výzkumný Ústav Vodohospodářský T. G. Masaryka/T. G. Masaryk Water Research Institute): Current Meters, 
available at: http://www.vuv.cz/index.php/en/58-cksvv-cz/ 180-current-meters, last access: 2 March 2017.

Wallén, A.: Chronique internationale union géodésique et géophysique internationale, Bulletin géodésique, 23, 130-149, 1929.

Woolf, H. and Cattell, A.: Eighty-Eighth Critical Bibliography of the History of Science and Its Cultural Influences, A Journal of the History Science Society, 54, 515-667, 1963.

World Meteorological Organization: Manual on Stream Gauging, Volume II - Computation of Discharge, WMO-No. 1044, Geneva, 197 pp., 2010.
Zhang, X., Yuan, L., Yan, P., Li, J., and He, X.: Rectangular sharp crested weir calibration for low head and clinging flow regime, Irrigation Sci., 33, 131-139, 2015.

Zhelezniakov, G. V.: The theoretical foundations of hydrometry, Hydrometeorological Press, Leningrad, 290 pp., 1968 (in Russian). 